\title{
Effects of Mulch and Irrigation System on Sweet Onion: I. Bolting, Plant Growth, and Bulb Yield and Quality
}

\author{
Juan C. Díaz-Pérez ${ }^{1}$ \\ Department of Horticulture, Coastal Plain Experiment Station, University of Georgia 31793-0748
}

William M. Randle

Department of Horticulture, University of Georgia, Athens, GA 30602

George Boyhan

Department of Horticulture, University of Georgia, Statesboro, GA 30460

Ronald W. Walcott

Department of Plant Pathology, University of Georgia, Athens, GA 30602

David Giddings and Denne Bertrand

Department of Horticulture, Coastal Plain Experiment Station, University of Georgia 31793-0748

Hunt F. Sanders and Ronald D. Gitaitis

Department of Plant Pathology, Coastal Plain Experiment Station, University of Georgia 31793-0748

AdDitional INDEX words. Allium cepa, root zone temperature, plasticulture, drip irrigation, soil water potential

\begin{abstract}
Sweet onions (Allium cepa L.) are typically grown on bare soil and irrigated with high-pressure systems such as sprinklers or center-pivots. The objective of this study was to determine the effects of irrigation system and mulch on bolting, bulb yield and bulb quality over 3 years. The experimental design was a split plot, where the main plot was irrigation system (drip or sprinkler) and the subplot was the type of mulch (bare soil, black plastic film or wheat straw). The results showed that individual bulb weight and bulb yields under drip irrigation were similar to those under sprinkler irrigation. Plants grown on bare soil had the highest total yield during the three seasons and among the highest marketable yield. There were no consistent differences in the bulb number or yield of plants on plastic film mulch compared to those of plants on wheat straw mulch. Plants on wheat straw mulch had reduced foliar nitrogen content. Variability in yields among mulches and seasons was partly explained by changes in seasonal root zone temperature and soil water potential. Total and marketable yields and weight of individual bulbs increased with increasing root zone temperatures up to an optimum at $15.8^{\circ} \mathrm{C}$, followed by reductions in yields and individual bulb weight at $>15.8$ ${ }^{\circ} \mathrm{C}$. Onion bolting increased with decreasing foliage nitrogen content, with plants on wheat straw having the highest bolting incidence. Bolting also increased with decreasing root zone temperatures for the season. Total and marketable yields increased with decreasing mean seasonal soil water potential down to $-30 \mathrm{kPa}$. Irrigation system and mulches had no consistent effect on the soluble solids content or pungency of onion bulbs.
\end{abstract}

Sweet ('Vidalia') onions represent the leading vegetable crop by value ( $\$ 75$ million) in Georgia (Boyhan and Torrance, 2002). During 2002, Vidalia onions in Georgia were planted to $\approx 5,900$ ha. In most onion-producing areas of Georgia, soils are sandy loams with low water-holding capacities. Soil moisture levels may affect the quality and yield of onions. Low moisture conditions in the soil are conducive to poor yields (Shock et al., 1998), while excessive soil moisture results in waste of irrigation water, nutrient leaching, and may lead to rots and poor bulb quality.

Unpublished estimates are that onion growers in Georgia apply an average of $300 \mathrm{~mm}$ of water during the growing season. There is interest among the Georgia growers for the potential use of drip

Received for publication 14 Mar. 2003. Accepted for publication 10 Nov. 2003. We are thankful to the Vidalia Onion Committee for partial funding of this study. Thanks also to B. Mullinix, Jr., for statistical assistance, to P. Conner and J. Ruter for reviewing the manuscript, to E. Folds for secretarial support and to G. Acuña for help with field and laboratory tasks. We acknowledge the support of the following donors: United Irrigation and Roberts Irrigation Products Inc., for drip tape, and Hydro Agri North America, Inc. for calcium nitrate liquid fertilizer. Mention of trade names in this publication does not imply endorsement by the University of Georgia of products named, nor criticism of similar ones not mentioned.

'Corresponding author; e-mail jcdiaz@tifton.uga.edu. irrigation as a means to increase water use efficiency. Onions in Georgia are typically irrigated with high-pressure systems such as sprinklers or center-pivots. However, sprinkler irrigation systems may have a lower water use efficiency compared to low pressure irrigation systems such as drip irrigation, particularly in shallow rooted crops such as onion (Al-Jamal et al., 2001). Drip irrigation is also expected to reduce the incidence and severity of bacterial diseases such as center rot of onion caused by Pantoea ananatis (Serrano) Mergaret, a major disease in Georgia. Water splashing by rain or sprinkler irrigation is a primary mechanism for spread of bacterial foliar pathogens, as shown for sour skin of onion caused by Pseudomonas cepacia (Teviotdale et al., 1989).

Drip irrigation alone or in combination with plastic mulches is widely used for vegetable production, particularly for tomatoes, peppers and melons (Lamont, 1993). However, drip irrigation and plastic mulches are not used for onion production in Georgia. The benefits associated with the use of plastic mulches for vegetable production include higher yields, earlier harvests, improved weed control, cleaner fruit and increased efficiency in the use of water and fertilizers. In southern Florida, onions produced on white-onblack or black mulches have higher marketable yields compared 
to onions on bare ground, with plants on white-on-black mulch having the highest yields (Vavrina and Roka, 2000). The objective of this study was to determine the effects of irrigation system (drip or sprinkler) and mulch (plastic film, wheat straw or bare soil) on bolting, bulb yield and bulb quality. In a companion article (Gitaitis et al., 2003), the effects of irrigation system and mulch on the incidence and epidemiology of center rot of onion are reported.

\section{Materials and Methods}

The experiments were conducted during the 1999-2000, 2000-01, and 2001-02 seasons at the University of Georgia's Blackshank Farm, Coastal Plain Experiment Station, Tifton, Ga. The soil was a Tifton Sandy Loam (a fine loamy, silicious thermic Plinthic Paledults) with a $\mathrm{pH}$ of 6.3 to 6.8.

In 1999-2000 and 2000-01, the experimental design was a split plot, where the main plot was irrigation system (drip vs sprinkler) and the subplot was mulch type [bare soil, black plastic film (38 $\mu \mathrm{m}$ thick) (PlastiTech, St. Remi, Quebec) or wheat straw]. Each subplot consisted of three 18.3-m-long beds, with a 1.8-m separation between the centers of adjacent beds. Each bed had four rows $23 \mathrm{~cm}$ apart, with a plant spacing of $15 \mathrm{~cm}$. In 2001-02, the experimental design was a split plot, where the main plot was irrigation (drip vs. sprinkler) and the subplot was mulch type (bare and wheat straw), and each subplot consisted of a single 15.2-m-long bed.

In drip-irrigated plots, there were two lines of drip tape per bed, each drip tape being located midway between rows in alternate rows. The drip tape [T-Tape, T-Systems International Inc., San Diego, Calif. (1999-2000) and Ro-Drip, Roberts Irrigation Products Inc., San Marcos, Calif. (2000-01 and 2001-02)] had $20 \mathrm{~cm}$ (1999-2000 and 2000-01) or $10 \mathrm{~cm}(2001-02)$ emitter spacing, $1.02 \mathrm{~L} \cdot \mathrm{h}^{-1}(1999-2000$ and $2000-01)$ or $0.50 \mathrm{~L} \cdot \mathrm{h}^{-1}(2001-02)$ emitter flow at $5631 \mathrm{~kg} \cdot \mathrm{m}^{-2}$ pressure, $0.2-\mathrm{mm}$ wall thickness, and was either placed on top of the bed (1999-2000) or buried $3 \mathrm{~cm}$ deep (2000-01 and 2001-02).

Irrigation was applied as a complement to rainfall. Cumulative seasonal rainfalls were 384 mm (1999-2000), 475 mm (2000-01) and $330 \mathrm{~mm}(2001-02)$. Plants were irrigated with an average of 4 $\mathrm{mm}$ per week in one weekly application from transplanting to the period of rapid bulb enlargement (mid-March). From the period of rapid bulb enlargement to bulb harvest, plants were irrigated with an average of $12 \mathrm{~mm} /$ week in one to two weekly applications.

All plots were fertilized with $1120 \mathrm{~kg} \cdot \mathrm{ha}^{-1}(1999-2000)$ or 896 $\mathrm{kg} \cdot \mathrm{ha}^{-1}(2000-01$ and 2001-02) of a $5 \mathrm{~N}-4.4 \mathrm{P}-15 \mathrm{~K}$ fertilizer, plus an additional $336 \mathrm{~kg} \cdot \mathrm{ha}^{-1}$ of a $0 \mathrm{~N}-0 \mathrm{P}-22 \mathrm{~K}$ magnesium-containing fertilizer before planting, followed by $146 \mathrm{~kg} \cdot \mathrm{ha}^{-1}$ of an $18 \mathrm{~N}-20.2 \mathrm{P}-0 \mathrm{~K}$ fertilizer immediately after transplanting. Sprinkler-irrigated plots were side-dressed with a $15 \mathrm{~N}-0 \mathrm{P}-14 \mathrm{~K}$ fertilizer at $112 \mathrm{~kg} \cdot \mathrm{ha}^{-1}$ 4 and 8 weeks after transplanting (WAT), calcium nitrate at 123 $\mathrm{kg} \cdot \mathrm{ha}^{-1}(12 \mathrm{WAT})$ and $148 \mathrm{~kg} \cdot \mathrm{ha}^{-1}$ (14 WAT), and potassium nitrate at $26 \mathrm{~kg} \cdot \mathrm{ha}^{-1}(12 \mathrm{WAT})$ and $30 \mathrm{~kg} \cdot \mathrm{ha}^{-1}(14 \mathrm{WAT})$. Drip-irrigated plants were fertilized ( $\mathrm{N}$ and $\mathrm{K}$ ) weekly through the drip tape with a $15 \mathrm{~N}-0 \mathrm{P}-14 \mathrm{~K}$ fertilizer at $28 \mathrm{~kg} \cdot \mathrm{ha}^{-1}$ per week from 5 WAT to 12 WAT, calcium nitrate at $62 \mathrm{~kg} \cdot \mathrm{ha}^{-1}$ per week and potassium nitrate at $13 \mathrm{~kg} \cdot \mathrm{ha}^{-1}$ per week from 13 WAT to $15 \mathrm{WAT}$, and calcium nitrate at $31 \mathrm{~kg} \cdot \mathrm{ha}^{-1}$ per week and potassium nitrate at $6.5 \mathrm{~kg} \cdot \mathrm{ha}^{-1}$ per week on week 16 after transplanting.

Onion seedlings ('Sweet Vidalia', Sunseeds, Morgan Hill, Calif.) were transplanted on 2 Dec. 1999, 6 Dec. 2000, and 28 to 29 Nov. 2001. Beginning in February, foliar diseases caused by fungi were controlled with weekly applications of chlorothalonil (Syngenta, Basel, Switzerland) at $1.75 \mathrm{~L} \cdot \mathrm{ha}^{-1}$, alternating with iprodione (Aventis, Strasvourg, France) at $2.24 \mathrm{~L} \cdot \mathrm{ha}^{-1}$ every third week. When plant tops were about half the size of full mature plants, the vegetative tops of 10 plants per replication were dried at $70{ }^{\circ} \mathrm{C}$ for $2 \mathrm{~d}$ and analyzed for mineral nutrient content. Concentrations of $\mathrm{P}, \mathrm{K}, \mathrm{Ca}, \mathrm{Mg}, \mathrm{Fe}, \mathrm{Mn}, \mathrm{Zn}$, and $\mathrm{Cu}$ were determined by atomic absorption spectrophotometry. Tissue $\mathrm{N}$ concentration was determined by the copper catalyst (AOAC, 1990). Bolting incidence was determined just before harvest as the percent of plants with seed stems (flowering stems).

SoIL WATER POTENTIAL. Soil water potential was measured to account for soil moisture differences between irrigation or mulch treatments. Soil water potential (SWP) was measured with granular matrix sensors (model 200SS; water mark soil moisture sensor, Irrometer Co., Riverside, Calif.) at $0.1 \mathrm{~m}$ deep below one of the center rows in each plot. In the 1999-2000 and 2001-02 seasons soil moisture was determined manually three times a week, while in the 2000-01 season soil moisture was measured hourly with the sensors being connected to a datalogger (CR10X; Campbell Sci., Logan, Utah) and a multiplexer (AM416; Campbell Scientific). The datalogger was programmed to collect readings every $10 \mathrm{~min}$ and store hourly readings for each plot.

ROOT-ZONE TEMPERATURE AND AIR TEMPERATURE. Root zone temperature (RZT) over the growing season was measured by determining soil temperature midway between the plants at 10 $\mathrm{cm}$ below the mulch or soil surface. RZT was measured with copper-constantan thermocouples (model 105; Campbell Scientific, Logan, Utah) connected to a datalogger (CR10X; Campbell Scientific) and an relay multiplexer (AM416; Campbell Scientific). The datalogger was programmed to record readings every $10 \mathrm{~min}$ and store hourly averages for each plot. Air temperature data were obtained from a University of Georgia weather station located within $1 \mathrm{~km}$ of the plots.

Harvest. Plants were harvested when $20 \%$ of the necks had collapsed (tops down). Onions were undercut $48 \mathrm{~h}$ before harvest and the bulbs were allowed to field-cure. Onions were handharvested and roots and tops were clipped. In 2000, onions were harvested on 18 Apr., 25 Apr., and 3 May for black plastic, bare soil and straw mulch treatments, respectively. In 2001, harvest was on 20 Apr. for black plastic, and on 3 May for bare soil and straw mulch treatments, respectively. In 2002, all treatments were harvested on 3 May. After harvest, bulbs were cured for 3 to $5 \mathrm{~d}$ in a dryer at $37{ }^{\circ} \mathrm{C}$ air temperature $(50 \%$ to $65 \% \mathrm{RH})$ and a linear air velocity of $5 \mathrm{~m} / \mathrm{min}$ through the stack of onions (Boyhan et al., 2001). After curing, bulbs were graded by size and appearance as marketable or cull (U.S. Dept. of Agriculture, 1995), counted and weighed. After grading, a subsample of 10 marketable bulbs per replication was used for determination of soluble solids content (SSC) and pungency. Ten wedges from each bulb group were juiced in a pneumatic press. Several drops of the juice were applied to a hand-held refractometer (Kernco, Tokyo, Japan) to measure SSC. Gross flavor intensity for each treatment combination was also determined using the juice with the pyruvic acid method of Randle and Bussard (1993). Pyruvic acid is used routinely to measure onion flavor intensity (Lancaster and Boland, 1990). Data were analyzed using the Mixed Procedure of SAS (SAS Institute Inc., 2000).

\section{Results}

Mineral nUtrient CONCENTRATION OF Vegetative TOPS. Irrigation system did not consistently affect the mineral nutrient content of vegetative tops. Similarly, except for N, mulch did 
Table 1. Nitrogen concentration of onion tops when plant tops were about half the size of full mature plants during three growing seasons.

\begin{tabular}{lccc}
\hline & \multicolumn{3}{c}{$\mathrm{Nconcn}\left(\mathrm{mg} \cdot \mathrm{g}^{-1}\right)$} \\
\cline { 2 - 4 } Treatment & $1999-2000^{\mathrm{z}}$ & $2000-01^{\mathrm{z}}$ & $2001-02^{\mathrm{y}}$ \\
\hline Irrigation & & & \\
$\quad$ Drip & $28.8 \mathrm{a}^{\mathrm{x}}$ & $34.0 \mathrm{a}$ & $25.5 \mathrm{a}$ \\
$\quad$ Sprinkler & $30.0 \mathrm{a}$ & $31.3 \mathrm{~b}$ & $25.2 \mathrm{a}$ \\
Mulches & & & \\
$\quad$ Bare & $30.8 \mathrm{a}$ & $33.1 \mathrm{ab}$ & $27.0 \mathrm{a}$ \\
$\quad$ Plastic & $30.0 \mathrm{a}$ & $34.0 \mathrm{a}$ & --- \\
$\quad$ Straw & $27.4 \mathrm{~b}$ & $30.9 \mathrm{~b}$ & $23.7 \mathrm{~b}$ \\
Significance & & & \\
$\quad$ Irrigation (I) & 0.250 & 0.023 & 0.838 \\
$\quad$ Mulch (M) & 0.027 & 0.079 & 0.050 \\
I $\times$ M & 0.441 & 0.517 & 0.334 \\
\hline
\end{tabular}

z98 d after planting

y $120 \mathrm{~d}$ after planting

×Mean separation within columns by Fisher's protected LSD test $(P \leq 0.05)$.

not consistently affect the mineral nutrient concentration of the vegetative tops. The mean nutrient concentrations of the vegetative tops for the three seasons were $30.5 \mathrm{mg} \cdot \mathrm{g}^{-1} \mathrm{~N}, 2.2 \mathrm{mg} \cdot \mathrm{g}^{-1} \mathrm{P}$, $33.1 \mathrm{mg} \cdot \mathrm{g}^{-1} \mathrm{~K}, 4.9 \mathrm{mg} \cdot \mathrm{g}^{-1} \mathrm{Ca}, 2.3 \mathrm{mg} \cdot \mathrm{g}^{-1} \mathrm{Mg}, 259 \mathrm{mg} \cdot \mathrm{kg}^{-1} \mathrm{Fe}, 48$ $\mathrm{mg} \cdot \mathrm{kg}^{-1} \mathrm{Mn}, 39 \mathrm{mg} \cdot \mathrm{kg}^{-1} \mathrm{Zn}$, and $8 \mathrm{mg} \cdot \mathrm{kg}^{-1} \mathrm{Cu}$. Vegetative tops of plants grown on wheat straw had the lowest $\mathrm{N}$ content, while there was no significant difference in $\mathrm{N}$ content between plants grown on plastic mulch and those grown on bare soil (Table 1).

RZT (MAXIMUM, MINIMUM, MEAN FOR THE SEASON). Irrigation system did not consistently affect RZTs (Table 2). In 1999-2000 and 2001-02 seasons, mean RZTs were lower under drip than under sprinkler irrigation, while in 2000-01, the mean RZTs were similar between irrigation systems. Maximum and minimum RZTs were also similar between treatments during the three seasons, except for the lower maximal RZT under drip than under sprinkler in 2001-02. There were no differences in minimum RZTs between irrigation systems in the three seasons. Mean, maximum and minimum RZTs were highest under plastic mulch, with no consistent differences in RZTs between bare soil and straw mulch, although there were wider fluctuations in RZT in bare soil than under wheat straw. Overall mean seasonal RZT increased with increasing average mean air temperature for the season (data not shown). Average mean, maximum and minimum air temperatures were highest in 2001-02 $\left(14.7,20.6\right.$, and $\left.8.9^{\circ} \mathrm{C}\right)$, followed by temperatures in 1999-2000 $\left(14.1,20.4\right.$, and $\left.7.8^{\circ} \mathrm{C}\right)$ and $2000-01\left(13.2,19.0\right.$, and $\left.7.5^{\circ} \mathrm{C}\right)$.
Soll Water Potential. Soil water potential (SWP) was not consistently affected by irrigation system but it was affected by mulch (Table 3). Depending on the season, soil water potential under plastic was the highest or as high as under straw, while soil water potential in bare soil was the lowest among mulch treatments.

BoLTiNG. Irrigation system did not consistently affect bolting, while the presence of mulch did influence bolting (Table 4). For each of the three seasons, plants grown with straw mulch had higher bolting incidences compared to plants on either bare soil or black plastic mulch. Bolting incidence with black plastic mulch was similar compared to that of bare soil. Bolting was associated with plant and environmental factors that were modified by the utilization of mulches. Data pooled over seasons showed that bolting incidence declined with increasing $\mathrm{N}$ content of the vegetative tops of the plants (Fig. 1). In all mulches, bolting declined with increasing RZTs during both the prebulbing stage (DAT $\leq 100)$ and the entire season (Fig. 2). However, bolting was not associated with RZT $\left(r^{2}=0\right)$ during the bulbing stage (DAT $\left.>100\right)$. The slopes of the bolting vs RZT relationship were similar in plastic and wheat straw mulches. Thus a single slope was calculated for the pooled data of both plastic and wheat straw. At the same RZT, bolting in bare soil was lower compared to bolting on either plastic mulch or wheat straw mulch. Bolting was not correlated with changes in mean seasonal SWP $\left(r^{2}=0\right)$.

YIELDS. Irrigation system did not consistently affect the mean bulb weight, the total number of bulbs or the number of jumbo bulbs, or the marketable and total yields (Tables 5 to 7). Onion plants grown on bare soil had the highest total yield during the three seasons and among the highest mean bulb weight, total number of bulbs or number of jumbo bulbs and marketable yield (Tables 5 to 7). There were no consistent differences in the bulb number or yield of plants on plastic film mulch and those under wheat straw mulch (Tables 5 and 6).

Total yield, marketable yield, total number of bulbs and weight of individual bulbs increased with increasing seasonal RZTs up to an optimum at $15.8^{\circ} \mathrm{C}$, followed by reductions in yields and individual bulb weight at $>15.8^{\circ} \mathrm{C}$ (Fig. 3). The optimal seasonal RZT for yields and bulb weight were calculated by setting the first derivative of the equations in Fig. $2=0$ (Díaz-Pérez and Batal, 2002). Seasonal RZT of onion plants on bare soil was closer to the optimal seasonal RZT, compared to the seasonal RZT of plants on either wheat straw or plastic mulch. Root zone temperature was associated with onion yields differently, depending on the growth stage. Root zone temperature during the prebulbing stage fit qua-

Table 2. Average seasonal root zone temperatures in sweet onion as affected by irrigation system and mulch during the 1999-2000, 2000-01, and 2001-02 growing seasons in Tifton, Ga.

\begin{tabular}{|c|c|c|c|c|c|c|c|c|c|}
\hline \multirow[b]{3}{*}{ Treatment } & \multicolumn{3}{|c|}{ 1999-2000 } & \multicolumn{3}{|c|}{$2000-01$} & \multicolumn{3}{|c|}{$2001-02$} \\
\hline & \multicolumn{9}{|c|}{ Temp $\left({ }^{\circ} \mathrm{C}\right)$} \\
\hline & Mean & $\operatorname{Max}$ & Min & Mean & $\operatorname{Max}$ & Min & Mean & $\operatorname{Max}$ & Min \\
\hline \multicolumn{10}{|l|}{ Irrigation } \\
\hline Drip & $15.48 \mathrm{~b}$ & $18.54 \mathrm{a}$ & $12.93 \mathrm{a}$ & $16.72 \mathrm{a}$ & $19.66 \mathrm{a}$ & $14.30 \mathrm{a}$ & $13.95 \mathrm{~b}$ & $17.85 \mathrm{~b}$ & $10.89 \mathrm{a}$ \\
\hline Sprinkler & $15.61 \mathrm{a}$ & $18.75 \mathrm{a}$ & $12.98 \mathrm{a}$ & $16.72 \mathrm{a}$ & $19.58 \mathrm{a}$ & $14.34 \mathrm{a}$ & $14.01 \mathrm{a}$ & $18.02 \mathrm{a}$ & $10.84 \mathrm{a}$ \\
\hline \multicolumn{10}{|l|}{ Mulch } \\
\hline Bare & $15.01 \mathrm{c}$ & $17.21 \mathrm{c}$ & $13.11 \mathrm{~b}$ & $16.40 \mathrm{~b}$ & $19.98 \mathrm{~b}$ & $13.55 \mathrm{c}$ & $14.12 \mathrm{a}$ & $18.24 \mathrm{a}$ & $10.89 \mathrm{a}$ \\
\hline Plastic & $16.21 \mathrm{a}$ & $19.57 \mathrm{a}$ & $13.71 \mathrm{a}$ & $17.46 \mathrm{a}$ & $20.29 \mathrm{a}$ & $15.06 \mathrm{a}$ & ---- & ---- & ---- \\
\hline Straw & $15.42 \mathrm{~b}$ & $19.16 \mathrm{~b}$ & $12.04 \mathrm{c}$ & $16.30 \mathrm{c}$ & $18.59 \mathrm{c}$ & $14.36 \mathrm{~b}$ & $13.85 \mathrm{~b}$ & $17.63 \mathrm{~b}$ & $10.83 \mathrm{~b}$ \\
\hline \multicolumn{10}{|l|}{ Significance } \\
\hline Irrigation (I) & $<0.01$ & $<0.01$ & 0.149 & 0.865 & 0.246 & 0.222 & 0.049 & $<0.01$ & 0.075 \\
\hline Mulch (M) & $<0.01$ & $<0.01$ & $<0.01$ & $<0.01$ & $<0.01$ & $<0.01$ & $<0.01$ & $<0.01$ & 0.042 \\
\hline $\mathrm{I} \times \mathrm{M}$ & $<0.01$ & 0.044 & $<0.01$ & $<0.01$ & $<0.01$ & $<0.01$ & $<0.01$ & $<0.01$ & 0.012 \\
\hline
\end{tabular}

${ }^{2}$ Mean separation $(\mathrm{n}=150$ daily measurements) within columns by Fisher's protected LSD test $(P \leq 0.05)$. 
Table 3. Average seasonal soil water potential in sweet onion as affected by irrigation system and mulch during three growing seasons.

\begin{tabular}{lccc}
\hline & \multicolumn{3}{c}{ Soil water potential (-kPa) } \\
\cline { 2 - 4 } Treatment & $1999-00$ & $2000-01$ & $2001-02$ \\
\hline Irrigation & $28 \mathrm{a}$ & $10 \mathrm{~b}$ & $7 \mathrm{a}$ \\
$\quad$ Drip & $22 \mathrm{~b}$ & $15 \mathrm{a}$ & $7 \mathrm{a}$ \\
$\quad$ Sprinkler & $31 \mathrm{a}$ & $17 \mathrm{a}$ & $9 \mathrm{a}$ \\
Mulch & $23 \mathrm{~b}$ & $9 \mathrm{c}$ & --- \\
$\quad$ Bare & $21 \mathrm{~b}$ & $11 \mathrm{~b}$ & $6 \mathrm{~b}$ \\
$\quad$ Plastic & & & \\
Straw & 0.019 & $<0.001$ & 0.853 \\
Significance & 0.003 & $<0.001$ & $<0.001$ \\
$\quad$ Irrigation (I) & 0.252 & $<0.001$ & 0.325 \\
$\quad$ Mulch (M) & & \\
I $\times$ M &
\end{tabular}

zMean separation within columns by Fisher's protected LSD test $(P \leq 0.05)$.

Table 4. Bolting incidence of sweet onion plants as affected by irrigation system and mulch type during three growing seasons.

\begin{tabular}{lccc}
\hline & \multicolumn{3}{c}{ Bolting (\%) } \\
\cline { 2 - 4 } Treatment & $1999-00$ & $2000-01$ & $2001-02$ \\
\hline Irrigation & $11 \mathrm{a}$ & $2.4 \mathrm{a}$ & $7 \mathrm{a}$ \\
$\quad$ Drip & $7 \mathrm{a}$ & $1.3 \mathrm{~b}$ & $12 \mathrm{a}$ \\
$\quad$ Sprinkler & & & \\
Mulch & $3 \mathrm{~b}$ & $0.3 \mathrm{~b}$ & $4 \mathrm{~b}$ \\
$\quad$ Bare & $6 \mathrm{~b}$ & $0.4 \mathrm{~b}$ & --- \\
$\quad$ Plastic & $17 \mathrm{a}$ & $4.8 \mathrm{a}$ & $15 \mathrm{a}$ \\
$\quad$ Straw & & & \\
Significance & 0.579 & 0.02 & 0.252 \\
$\quad$ Irrigation (I) & $<0.001$ & $<0.001$ & $<0.001$ \\
Mulch (M) & 0.184 & 0.013 & 0.104 \\
I $\times$ M & &
\end{tabular}

zMean separation within columns by Fisher's protected LSD test $(P \leq 0.05)$.

dratic relationships with total $\left(\mathrm{y}=-5.32 \mathrm{x}^{2}+140.3 \mathrm{x}-872.5 ; R^{2}=\right.$ 0.48; optimal RZT $\left.=13.2^{\circ} \mathrm{C}\right)$ and marketable yields $\left(\mathrm{y}=-4.11 \mathrm{x}^{2}\right.$ $+109.8 \mathrm{x}-694.8 ; R^{2}=0.50$; optimal $\left.\mathrm{RZT}=13.4^{\circ} \mathrm{C}\right)$, number of bulbs $\left(\mathrm{y}=-10.35 \mathrm{x}^{2}+275.0 \mathrm{x}-1661.4 ; R^{2}=0.41\right.$; optimal $\mathrm{RZT}$

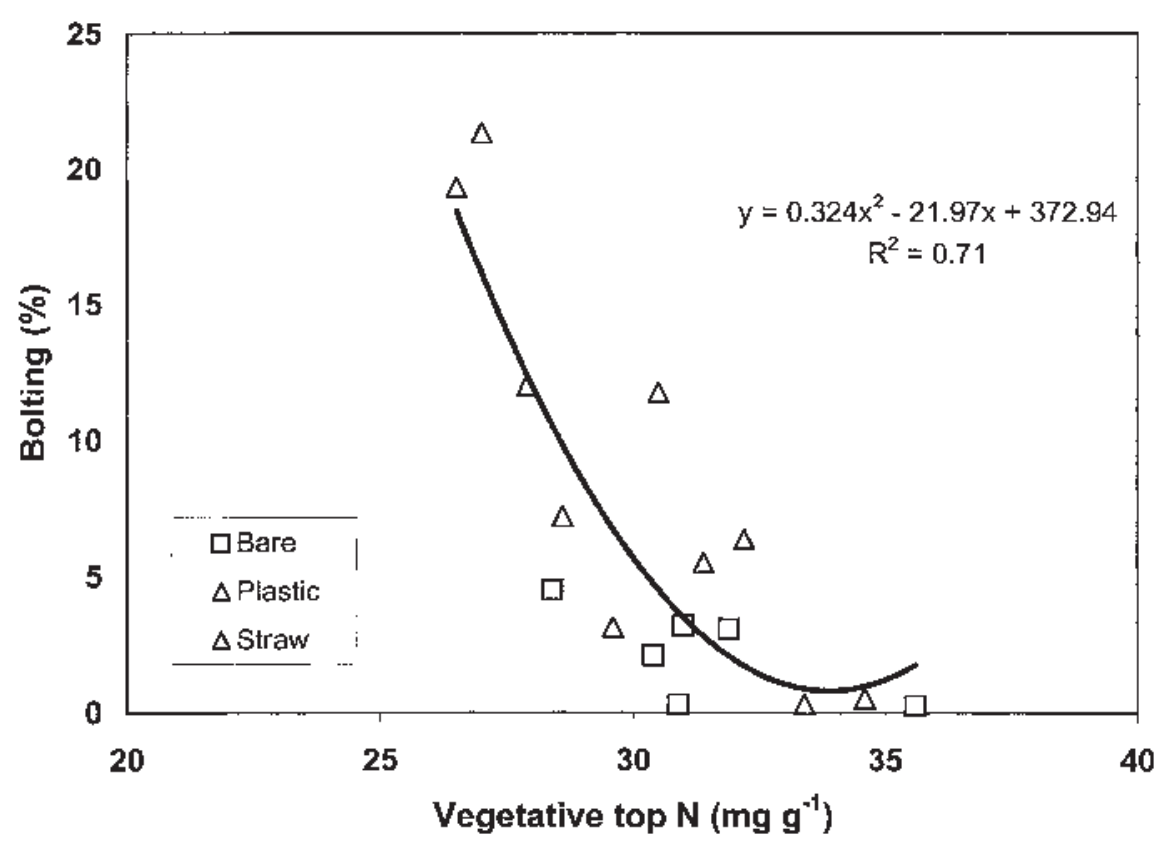

$\left.=13.3^{\circ} \mathrm{C}\right)$, and individual bulb weight $\left(\mathrm{y}=-0.018 \mathrm{x}^{2}+0.486 \mathrm{x}\right.$ $-2.887 ; R^{2}=0.601$; optimal $\mathrm{RZT}=13.5^{\circ} \mathrm{C}$ ). During the bulbing stage ( $\geq 100$ DAT), total and marketable yields and total number of bulbs increased with increasing mean RZT from 18 to $20.5^{\circ} \mathrm{C}$ (Fig. 3). From our data, we were unable to detect an upper limit RZT for onion yields during the bulbing stage. The weight of individual bulbs was not associated with the changes in RZT during the bulbing stage.

Total and marketable yields, number of bulbs and individual bulb weight increased with decreasing SWP down to $-30 \mathrm{kPa}$ (Fig. 4). Onion yields were highest in 1999-2000 and lowest in 2001-02.

BULB QUALITY. Irrigation system and mulch type had no effect on the soluble solids content (SSC) or pungency of onion bulbs (data not shown). The mean SSC values were $8.5 \%$ and $7.3 \%$, and the mean pungency values were 3.5 and $3.8 \mu \mathrm{mol}$ pyruvate $/ \mathrm{mL}$, for 1999-2000 and 2000-01, respectively.

\section{Discussion}

Onion bulb yield was affected by mulch and varied among seasons, but was minimally affected by irrigation system. Mulches may increase or decrease RZT, depending on how the mulch affects the energy balance of the soil (Liakatas et al., 1986). In this study, black plastic mulch resulted in the highest RZT, which is consistent with numerous reports that show that RZT under black mulch may be at least $2{ }^{\circ} \mathrm{C}$ higher compared to bare soil (DiazPerez and Batal, 2002; Lamont, 1993). The variability in yields among mulches and seasons was partly explained by the changes in seasonal RZTs. Onion yields, number of bulbs and individual bulb weight fit quadratic relationships with both RZT during the prebulbing stage and with mean seasonal RZT. RZT during the prebulbing stage was associated with yields probably by affecting the balance between vegetative and reproductive growth in the onion plant (Brewster, 1983; Rabinowitch, 1990). During the bulbing stage, increases in RZT were associated with yield increases. This indicates that, once bulbing is initiated, presence of warm conditions is required for bulb growth.

Under the environmental conditions of the study, onion plants on bare soil yielded more than plants on either black plastic mulch or wheat straw mulch. Yields on bare soil were highest probably because seasonal RZTs were closer to the optimal RZT $\left(15.8^{\circ} \mathrm{C}\right)$ for onion. However, the response of onions to plastic mulch or wheat straw mulch utilization has to be interpreted with caution because it is possible that under air and RZT conditions different from those of this study, onion plants may respond differently to black plastic mulch or wheat straw utilization, as suggested by the relationship of onion yield with RZT (Fig. 3). In tomato, plant growth and yield under colored mulches varies among seasons, and this variability has been associated with the RZTs under colored plastic film mulches (Díaz-Pérez and Batal, 2002). In onions grown in southern Florida, yields were higher in plants grown on white-on-black plastic

Fig. 1. Bolting as a function of the nitrogen content of the vegetative top of the onion plant. Graphs were constructed with data from the 1999-2000, 2000-2001, and 2001-2002 seasons. Each symbol represents the mean of four replications per mulch (black plastic film, wheat straw, or bare soil). 

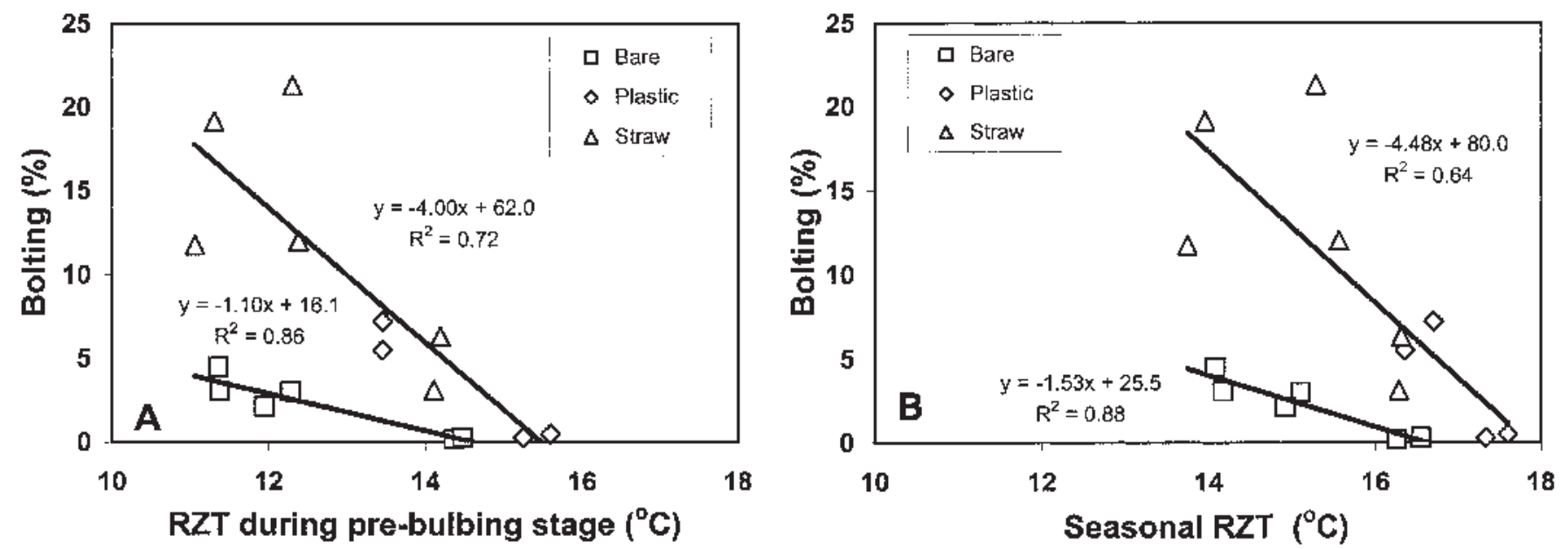

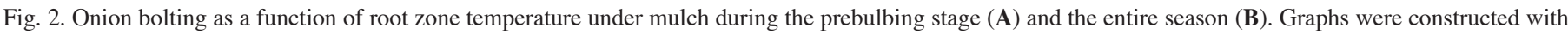

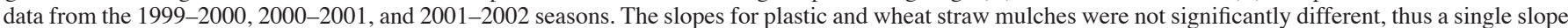
was calculated for the pooled data of both plastic and wheat straw. Each symbol represents the mean of four replications per mulch (black plastic film, wheat straw, or bare soil).

mulch than those on black mulch, while yields on bare soil were the lowest (Vavrina and Roka, 2000).

The variability in yields among mulches and seasons was also explained by the mean SWP to which plants were exposed during the season. In all seasons, high SWP (i.e., high soil moisture) was associated with reductions in bulb size and bulb number. Total and marketable yields, number of bulbs and individual bulb weight increased with decreasing mean SWP down to $-30 \mathrm{kPa}$ (Fig. 4). The high yields of plants on bare soil were associated with reduced
SWPs compared to plants on either black plastic mulch or wheat straw mulch. Similarly, an unpublished study (Díaz-Pérez) of dripirrigated onion grown on either wheat straw mulch or bare soil showed that total yield of onion under drip irrigation increased with decreasing seasonal SWP (Total yield $=-2.49 \mathrm{SWP}+7.8 ; r^{2}=$ $0.57^{* *}$ ) for the season of plants irrigated at $60 \%, 80 \%, 100 \%$, or $120 \%$ Reference Evapotranspiration(ET). Occurrence of higher SWPs in the soils covered with black plastic mulch or wheat straw compared to bare soil was expected because mulches are known to reduce

Table 5. Yields of sweet onion as affected by irrigation system and mulch of plants during the 1999-2000 season.

\begin{tabular}{|c|c|c|c|c|c|}
\hline Treatment & $\begin{array}{c}\text { Bulb size } \\
\text { (g/bulb) }\end{array}$ & $\begin{array}{c}\text { Jumbo } \\
(\times 1000 / \mathrm{ha})\end{array}$ & $\begin{array}{l}\text { Marketable } \\
\text { wt }\left(\mathrm{t}^{-} \cdot \mathrm{ha}^{-1}\right)\end{array}$ & $\begin{array}{c}\text { Total } \\
(\times 1000 / \mathrm{ha})\end{array}$ & $\begin{array}{c}\text { Total wt } \\
\left(t \cdot h a^{-1}\right)\end{array}$ \\
\hline \multicolumn{6}{|l|}{ Irrigation } \\
\hline Drip & $299 \mathrm{~b}$ & $77 \mathrm{a}$ & --- & $178 \mathrm{~b}$ & $53 \mathrm{~b}$ \\
\hline Sprinkler & $320 \mathrm{a}$ & $89 \mathrm{a}$ & --- & $183 \mathrm{a}$ & $59 \mathrm{a}$ \\
\hline \multicolumn{6}{|l|}{ Mulches } \\
\hline Bare & 329 a & $88 \mathrm{a}$ & --- & $183 \mathrm{a}$ & $60 \mathrm{a}$ \\
\hline Plastic & $291 \mathrm{~b}$ & $67 \mathrm{~b}$ & --- & $176 \mathrm{~b}$ & $52 \mathrm{c}$ \\
\hline Straw & $308 \mathrm{ab}$ & $95 \mathrm{a}$ & --- & $181 \mathrm{ab}$ & $56 \mathrm{~b}$ \\
\hline \multicolumn{6}{|l|}{ Significance } \\
\hline Irrigation (I) & 0.017 & 0.062 & --- & 0.026 & $<0.001$ \\
\hline Mulch (M) & 0.002 & 0.001 & --- & 0.035 & $<0.001$ \\
\hline $\mathrm{I} \times \mathrm{M}$ & 0.777 & 0.706 & --- & 0.117 & 0.716 \\
\hline
\end{tabular}

${ }^{\mathrm{z} M e a n}$ separation within columns by Fisher's protected LSD test $(P \leq 0.05)$.

Table 6. Yields of sweet onion as affected by irrigation system and mulch of plants during the 2000-01 season.

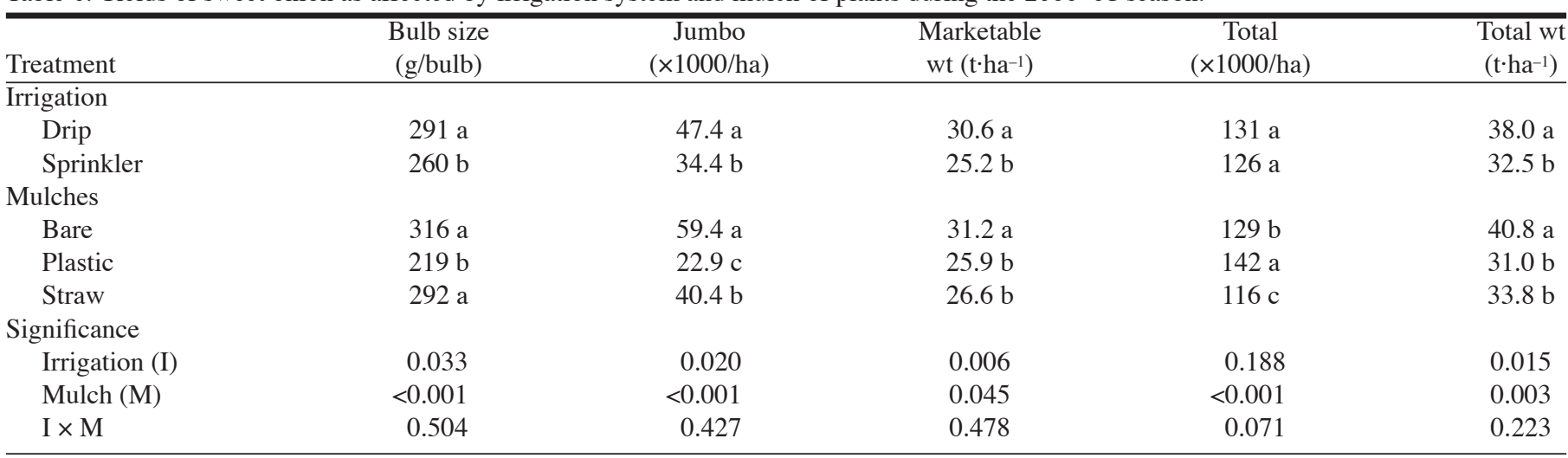

zMean separation within columns by Fisher's protected LSD test $(P \leq 0.05)$. 
Table 7. Yields of sweet onion as affected by irrigation system and mulch of plants during the 2001-02 season.

\begin{tabular}{|c|c|c|c|c|c|}
\hline Treatment & $\begin{array}{c}\text { Bulb size } \\
\text { (g/bulb) }\end{array}$ & $\begin{array}{c}\text { Jumbo } \\
(\times 1000 / \mathrm{ha})\end{array}$ & $\begin{array}{l}\text { Marketable } \\
\text { wt }\left(\mathrm{t}^{-} \cdot \mathrm{ha}^{-1}\right)\end{array}$ & $\begin{array}{c}\text { Total } \\
(\times 1000 / \mathrm{ha})\end{array}$ & $\begin{array}{l}\text { Total wt } \\
\left(\mathrm{t} \cdot \mathrm{ha}^{-1}\right)\end{array}$ \\
\hline \multicolumn{6}{|l|}{ Irrigation } \\
\hline Drip & $251 \mathrm{a}$ & $23 \mathrm{a}$ & $15.7 \mathrm{a}$ & $111 \mathrm{a}$ & $28.2 \mathrm{a}$ \\
\hline Sprinkler & $231 \mathrm{~b}$ & $17 \mathrm{a}$ & $15.3 \mathrm{a}$ & $107 \mathrm{a}$ & $25.2 \mathrm{a}$ \\
\hline \multicolumn{6}{|l|}{ Mulches } \\
\hline Bare & $259 \mathrm{a}$ & $28 \mathrm{a}$ & $18.6 \mathrm{a}$ & $126 \mathrm{a}$ & $32.8 \mathrm{a}$ \\
\hline Plastic & --- & --- & --- & --- & --- \\
\hline Straw & $223 \mathrm{~b}$ & $12 \mathrm{~b}$ & $12.5 \mathrm{~b}$ & $92 \mathrm{~b}$ & $20.5 \mathrm{~b}$ \\
\hline \multicolumn{6}{|l|}{ Significance } \\
\hline Irrigation (I) & 0.001 & 0.072 & 0.781 & 0.425 & 0.080 \\
\hline $\operatorname{Mulch}(\mathrm{M})$ & $<0.001$ & 0.001 & 0.001 & $<0.001$ & $<0.001$ \\
\hline $\mathrm{I} \times \mathrm{M}$ & 0.008 & 0.072 & 0.120 & 0.532 & 0.440 \\
\hline
\end{tabular}

${ }^{\mathrm{z}}$ Mean separation within columns by Fisher's protected LSD test $(P \leq 0.05)$.

soil evaporation(Liakatas etal., 1986). These results suggest that sweet onions benefited from being grown under mild water stress conditions. Contrary to our results, several studies show that onion yield increases with increasing soil moisture conditions (Coelho Ferreira et al., 1996; Patel et al., 1992; Rana and Sharma, 1993, 1994; Shock et al., 1998), with the optimum irrigation threshold being between $-12 \mathrm{kPa}$ (Shock et al., 1998) and -60 kPa (Hedge, 1986; Narang and Dastane, 1969). In our study, we did not irrigate using irrigation thresholds. However, the lowest mean SWP values in this study $(-30 \mathrm{kPa})$ corresponded to an average minimum SWP of about $-60 \mathrm{kPa}$. Possibly, onion yields in this study decreased with increasing SWP due to the increased bulb decay under high soil moisture conditions.

Consistent with a previous report (DíazPérez et al., 2003), bolting was associated with reduced $\mathrm{N}$ levels in the plant. Compared to plants on either bare soil or black plastic mulch, onion bolting was highest and plant $\mathrm{N}$ levels were lowest in plants grown on wheat straw mulch. Possibly, the presence of straw on the soil surface resulted in reduced soil $\mathrm{N}$ available for the plants because the microorganisms associated with straw decomposition competed with plants for soil N. Low plant N levels and high populations of microorganisms associated with straw decomposition may also be factors that explain the reduced bulb decay incidence of plants on wheat straw (Gitaitis et al., 2004). In this study, bolting was associated with low temperatures, consistent with previous reports (Rabinowitch,

Fig. 3. Total yield, marketable yield, total number of bulbs and weight of individual onion bulbs as affected by root zone temperature during the bulbing stage and by the mean seasonal root zone temperature. Graphs were constructed with data from the 1999-2000, 2000-2001, and 2001-2002 seasons. Each symbol represents the mean of four replications per mulch (black plastic film, wheat straw, or bare soil). Solid lines were fit by linear regression.
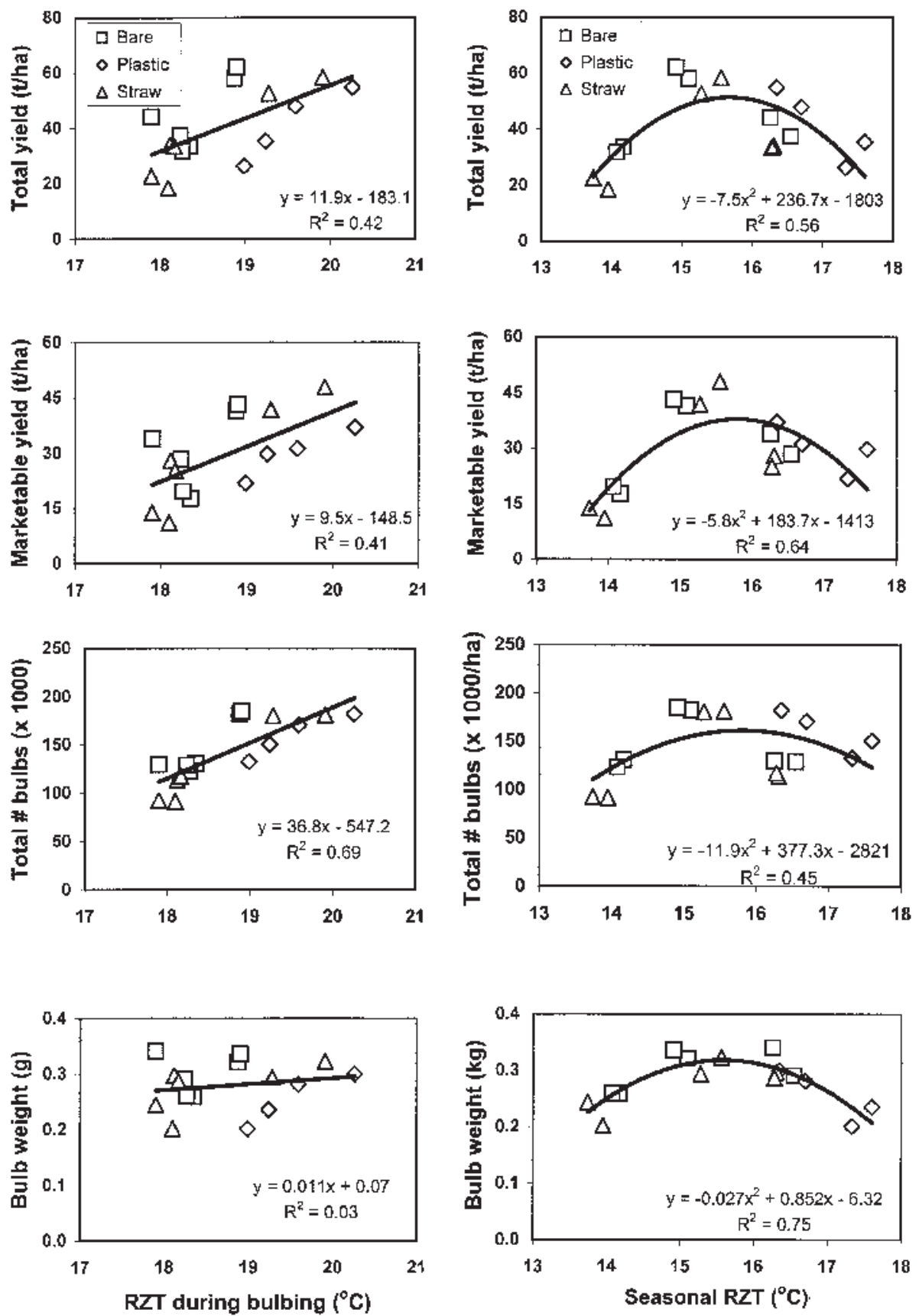

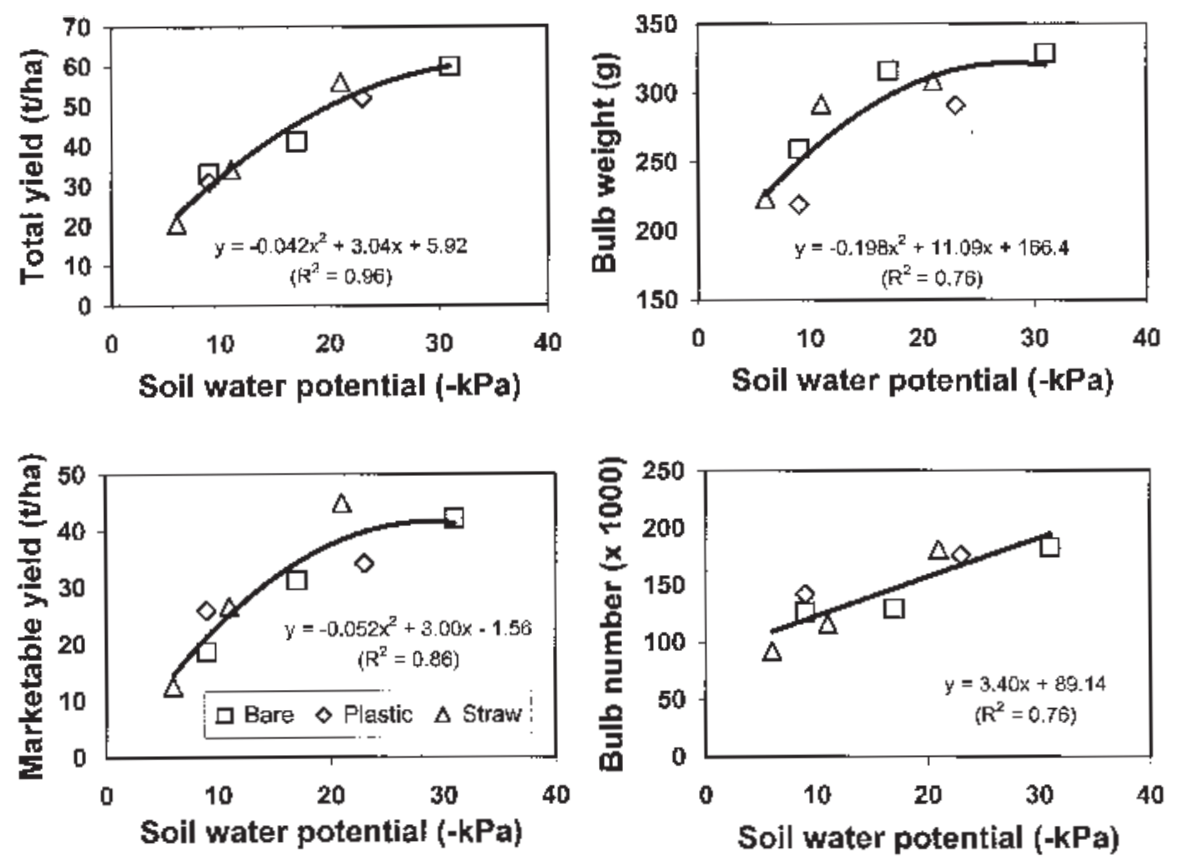

production in southeastern Georgia. HortTechnology 12:196-202.

Brewster, J.L. 1983. Effects of photoperiod, nitrogen nutrition and temperature on inflorescence initiation and development in onion (Allium cepa L.). Ann. Bot. 51:429-440.

Coelho Ferreira, E., A.B. de Souza, and M.A. Fonseca Conceiçao. 1996. Comportamento da cultura da cebola em três regimes de irrigaçâo e cinco espaçamentos. Pesq. Agropec. Bras. 31: 585-591.

Díaz-Pérez, J.C. and K.D. Batal. 2002. Colored plastic film mulches affect tomato growth and yield via changes in root-zone temperature. J. Amer. Soc. Hort. Sci. 127:127-136.

Díaz-Pérez, J.C., A. Purvis, and J.T. Paulk. 2003. Bolting, yield and bulb decay of sweet onion as affected by nitrogen fertilization. J. Amer. Soc. Hort. Sci. 128: 144-149.

Gitaitis, R.D., R.R. Walcott, H.F. Sanders, L. Zolobowska, and J.C. Díaz-Pérez. 2004. Effects of mulch and irrigation system on sweet onion: II. The epidemiology of center rot. J. Amer. Soc. Hort. Sci.129(2):225-230.

Hedge, D.M. 1986. Effect of irrigation regimes on dry matter production, yield, nutrient uptake and

Fig. 4. Total yield, marketable yield, weight of individual bulbs and total number of onion bulbs as a function of the mean seasonal soil water potential. Graphs were constructed with data from the 1999-2000, 2000-2001, and 2001-2002 seasons. Each symbol represents the means per mulch (black plastic film, wheat straw or bare soil). Solid lines were fit by linear regression.

1990). However, the presence of mulch (either plastic film or wheat straw) modified the way RZT affected bolting. At the same RZT conditions, bolting in bare soil was lower compared to that in either plastic mulch or wheat straw, suggesting that bolting is affected by factors other than temperature.

Onion quality may be influenced by environmental factors such as soil temperature that affect onion pungency (Yamaguchi et al., 1975). In this study, the soluble solids content (SSC) and pungency of bulbs were not affected by either irrigation system or mulch. However, mulches affected other bulb quality attributes such as bulb decay. Bulbs from plants grown on plastic mulch tended to have a higher incidence of bacterial diseases compared to bulbs from plants on bare soil or straw (Gitaitis et al., 2004). It is possible that variations in bulb decay among mulches are related to differences in root zone temperature and soil water potential as affected by mulches.

In summary, plants on bare soil yielded more than plants on either black plastic film mulch or wheat straw mulch. Yield differences among mulches and seasons were associated with differences in root zone temperatures and soil water potentials. Drip-irrigated onion plants yielded similarly as plants under sprinkler irrigation.

\section{Literature cited}

Al-Jamal, M.S., S. Ball, and T.W. Sammis. 2001. Comparison of sprinkler, trickle and furrow irrigation efficiencies for onion production. Agr. Water Mgt. 46:253-266.

AOAC. 1990. Official Methods of Analysis. Assn. Offic. Anal. Chem., Wash., D.C.

Boyhan, G.E., D.M. Granberry, and W.T. Kelley (eds.). Onion production guide. 2001. Univ. Ga. College Agr. Environ. Sci. Bul. 801.

Boyhan, G.E. and R.L. Torrance. 2002. Vidalia onions - Sweet onion water use in onion. Indian J. Agron. 31:343-348.

Lamont, Jr., W.J.1993. Plastic mulches for the production of vegetable crops. HortTechnology 3:35-39.

Lancaster, J.E. and M.J. Boland. 1990. Flavor biochemistry, p. 33-72. In: H.D. Rabinowich and J.L. Brewester (eds.). Onions and allied crops. vol. 3. CRC Presss, Boca Raton, Fla.

Liakatas, A., J.A. Clark, and J.L. Monteith. 1986. Measurements of the heat balance under plastic mulches. Agr. For. Meteorol. 36:227-239.

Narang, R.S. and N.G. Dastane. 1969. Water use by Allium cepa L. (bulb onions) grown under different soil moisture regimes. Indian J. Hort. 26:176-180.

Patel, K.P., J.C. Patel, B.S. Patel, and S.G. Sadaria. 1992. Yield and nutrient uptake by onion (Allium cepa) as influenced by irrigation, nitrogen and phosphorus. Indian J. Agron. 37:395-396.

Rabinowitch, H.D. 1990. Physiology of flowering, p. 113-134. In: H.D. Rabinowitch and J. L. Brewster (eds.). Onions and allied crops. vol. 1. CRC Press, Inc., Boca Raton. onion (Allium cepa) as affected by irrigation and nitrogen. Indian J. Agron. 38:676-677.

Rana, D.S. and R.P. Sharma. 1994. Effect of irrigation regime and nitrogen fertilization on bulb yield and water use of onion (Allium cepa). Indian J. Agr. Sci. 64:223-226.

Randle, W.M. and M.L. Bussard. 1993. Streamlining onion pungency analysis. HortScience 28:60.

SAS Institute Inc. SAS/C OnlineDoc. release 7.00. 2000. SAS Inst., Cary, N.C.

Shock, C.C., E. B.G. Feibert, and L.D. Saunders. 1998. Onion yield and quality affected by soil water potential as irrigation threshold. HortScience 33:1188-1191.

Teviotdale, B.L., R.M. Davis, J.P. Guerard, and D.H.Harper. 1989. Effect of irrigation management on sour skin of onion. Plant Dis. 73:819-822.

U.S. Department of Agriculture. U.S. standards for grades of Bermudagranex-grano type onions. 1995. USDA, Wash., D.C.

Vavrina, C.S. and F.M. Roka. 2000. Comparison of plastic mulch and bare-ground production and economics for short-day onions in a semitropical environment. HortTechnology 10:326-330.

Yamaguchi, M.K., K.N. Paulson, N. Kinsella, and R.A. Bernhard. 1975. Effects of soil temperature on growth and quality of onion bulbs ( $\mathrm{Al}$ lium cepa L.). J. Amer. Soc. Hort. Sci. 415-419.
Rana, D.S. and R.P. Sharma. 1993. Growth analysis and bulb yield of 